\title{
Preliminary results of the Phase lla trial of a folate binding protein (FBP) adjuvant cancer vaccine (E39+GM-CSF) in ovarian and endometrial cancer patients to prevent recurrence
}

\author{
Julia Greene ${ }^{1 *}$, Erika Schneble ${ }^{1}$, John Berry ${ }^{1}$, Alfred Trappey', Timothy Vreeland ${ }^{1}$, Guy Clifton², William McGuire ${ }^{3}$, \\ George Maxwell ${ }^{3}$, Sathibalan Ponniah ${ }^{4}$, George Peoples ${ }^{5}$
}

From Society for Immunotherapy of Cancer 29th Annual Meeting

National Harbor, MD, USA. 6-9 November 2014

\section{Background}

FBP (aka Folate Receptor-a) is an immunogenic protein that is over-expressed in breast, endometrial (EC) and ovarian cancer (OC). FBP expression in malignant cells is 20-80 fold higher compared to the limited distribution in normal cells. We have completed enrollment of a Phase IIa clinical trial with E39, an HLA-A2 restricted, FBP peptide vaccine + GM-CSF. The vaccine is administered in the adjuvant setting to prevent recurrences in high-risk, EC and OC patients (pts) rendered clinically disease-free with standard-of-care therapy. Here, we summarize preliminary toxicity (tox), immunologic and clinical response to vaccination.

\section{Methods}

HLA-A2+ pts are enrolled into the vaccine group (VG) while HLA-A2- pts are being followed prospectively as an untreated control group (CG). Six monthly intradermal inoculations (V1-V6) of either $100 \mathrm{mcg}, 500 \mathrm{mcg}$, or $1000 \mathrm{mcg}$ of E39 + 250 mcg GM-CSF are administered during the primary vaccine series (PVS). In vivo immunologic responses are assessed by both local reactions (LR) after each inoculation and delayed hypersensitivity (DTH) reactions measured at baseline (R0) and after the PVS (R6). Recurrences are determined clinically. Data are means compared with a paired, t-test or Chi-square/ Fisher Exact test as appropriate.

'San Antonio Military Medical Center, Houston, TX, USA

Full list of author information is available at the end of the article

\section{Results}

47 pts have enrolled; 25 in the VG and 22 in the CG. There are no significant differences in age, grade, stage, or nodal status between groups (all $\mathrm{P}>0.20$ ). Overall, the vaccine was well-tolerated (max local tox: $96 \%$ Grade (Gr) 1, 4\% Gr 2; max systemic tox: $56.5 \%$ Gr 1 , $26.1 \%$ Gr 2, 4.3\% Gr 3). The LR significantly increased from V1 to V2 $(45.6 \mathrm{~mm} \pm 5.5 \mathrm{v} 71.9 \mathrm{~mm} \pm 6.6, \mathrm{p}<$ $0.01)$, and then plateaued between V3 and V6 $(93.4 \mathrm{~mm}$ $\pm 8.3 \mathrm{v} 102.4 \mathrm{~mm} \pm 10.6, \mathrm{p}=0.51)$. With 14 patients having completed the PVS, DTH trended toward an increase from R0 to R6 $(7.15 \mathrm{~mm} \pm 1.7 \mathrm{v} 15.8 \mathrm{~mm} \pm 4.2$, $\mathrm{p}=0.07$ ). After a median follow-up of 13 months, there have been $11 / 22(50 \%)$ recurrences in the CG compared to $8 / 25(32 \%)$ recurrences in the VG $(p=0.25)$.

\section{Conclusions}

Current results from this Phase IIa trial indicate the E39 vaccine is well-tolerated and elicits a strong in vivo immune response. Preliminarily, the vaccine appears to reduce the risk of recurrence in adjuvant treated EC and OC patients. In contrast to other FBP-directed cytotoxic agents, the E39 vaccine holds the promise of a sustained immunologic response and memory against FBP-expressing recurrences with minimal toxicity.

\section{References}

Phase I/IIa Trial of Folate Binding Protein Vaccine in Ovarian Cancer: Clinicaltrials.gov Unique identifying number: NCT01580696 


\section{Authors' details}

${ }^{1}$ San Antonio Military Medical Center, Houston, TX, USA. ${ }^{2}$ MD Anderson

Cancer Center, Houston, TX, USA. ${ }^{3}$ Inova Fairfax Hospital, Falls Church, VA USA. ${ }^{4}$ Uniformed Services University of the Health Sciences, Bethesda, MD, USA. ${ }^{5}$ CDVP, USUHS, Bethesda, MD, USA.

Published: 6 November 2014

doi:10.1186/2051-1426-2-S3-P74

Cite this article as: Greene et al.: Preliminary results of the Phase lla trial of a folate binding protein (FBP) adjuvant cancer vaccine (E39+GM-CSF) in ovarian and endometrial cancer patients to prevent recurrence.

Journal for ImmunoTherapy of Cancer 2014 2(Suppl 3):P74.

Submit your next manuscript to BioMed Central and take full advantage of:

- Convenient online submission

- Thorough peer review

- No space constraints or color figure charges

- Immediate publication on acceptance

- Inclusion in PubMed, CAS, Scopus and Google Scholar

- Research which is freely available for redistribution

Submit your manuscript at www.biomedcentral.com/submit
Ciomed Central 